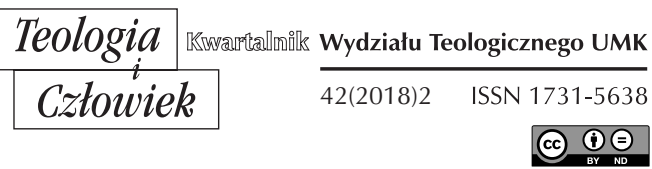

YONG LU*

WARSAW

ORCID: 0000-0003-3944-1885

\title{
THE HOLY SPIRIT ACCORDING TO THE GOSPEL OF LUKE
}

DOI: http://dx.doi.org/10.12775/TiCz.2018.015

Each Gospel has its unique messages of the Holy Spirit. First, Matthew's herald trumpet announces Jesus as King and prophetic fulfillment. The role of the church (ecclesiology) and the identification of Jesus (Christology) are two distinct elements of Matthew's presentation of the Holy Spirit. Second, Mark's percussion reflects the conflict, action and the role of servanthood. His reference to the Holy Spirit primarily shows the superiority of the ministry of Jesus over John's and identifies Jesus as the Messiah, the Son of God. Third, Luke's resonation declares joy, praise, prayer, and the bright wind of the Holy Spirit. The distinct works of the Holy Spirit in Luke and the Acts are respectively to witness to the ministry of Jesus and to bring about the working of salvation in

* Yong Lu, M.Sc., is a Ph.D candidate in Psychology at the Faculty of Christian Philosophy, Cardinal Stefan Wyszyński University in Warsaw (luyong@student.uksw.edu. pl; yong.lu@student.kuleuven.be; www.lu-yong.com). His research has mainly appeared in such journals as Integrative Psychological and Behavioral Science, Frontiers in Psychology, International Journal of Dream Research, Journal of Corporative Responsibility and Leadership, and others. He also has articles and presentations in several conferences and serves as a guest reviewer for several Chinese journals. 
the church (i.e., to give orders to Jesus' apostles and to enable to interpret the scriptures). ${ }^{1}$ Fourth, John's ponderous bass presents the divinity of infinite God becoming flesh.

This paper views messages from the Holy Spirit through the eyes of the Gospel writers in order to better understand how to apply the Scriptures to our knowledge of and practical experience with the Holy Spirit. ${ }^{2}$ Particular emphasis is placed on the writing of Luke which presents a unique message of the Holy Spirit by involving the Gospel writer's narrative on the life and ministry of Jesus. ${ }^{3}$

Concretely, in the following two sections, the present paper (1) identifies why Luke's writings are considered to be of significant importance to the study of the Holy Spirit's messages, (2) compares and contrasts Luke and Paul in their treatment of the messages of the Holy Spirit to their audience then, as well as its implications to the Church today, (3) describes how specific events in the life and ministry of Jesus are presented in Luke's writings to emphasize to the readers the moving of the Holy Spirit in those events, ${ }^{4}$ and (4) summarizes the importance of prayer to the moving of the Holy Spirit in our lives.

${ }^{1}$ Cf. D.A. Carson, D.J. Moo, and L. Morris, An Introduction to the New Testament, Grand Rapids, Michigan: Zondervan Publishing House 2005, pp. 121, 125.

${ }^{2}$ It is noteworthy that a purely harmonistic approach to study the role of the Holy Spirit from only one gospel author puts the unity of the Church at risk. Since each author only addresses each distinctive perspective on the Holy Spirit, when one group tries to champion one author's pneumatology over another, misunderstanding, divisions, and pain ensue.

${ }^{3}$ Since Luke is identified as a fellow-laborer (Philemon 24) and "the beloved physician" (Colossians 4:14), his occupation and education endow him an orderly manner and a careful scholar, which guarantees him using the best sources available in an effort to give an accurate and well-structured account on writing the message of Jesus. For example, we could infer that owing to his rigorous fact-based training by his physician occupation, Luke utilizes the testimony of identification, such as he mentions the "eyewitnesses and servants of the word" (Luke 1:2), to strengthen the reliability of his testimony.

${ }^{4}$ Specifically, the account of the birth of Jesus is recorded only by the Luke narrative in the four Gospels. Parables portrayed God's love for the unlovable, such as "Pharisee and the Publican", "Prodigal Son", "Good Samaritan", and "Rich Man and Lazarus", are came only from Luke. Therefore, some call Luke the "Loveliest Book in the World" as splendid parables of our Lord would not be known otherwise. Cf. B. Groves, The Gospel According to Luke: Commentary, Abilene, TX: Quality Publications 1991. 


\section{THE ROLE OF THE HOLY SPIRIT IN THE GOSPEL OF LUKE}

It is particularly important to study Luke's presentation of the role of the Holy Spirit. Luke tells us that Jesus was praying when the Holy Spirit came upon Him at His baptism (Luke 3:21-22). The Holy Spirit and its gifts and miracles throughout his Gospel and the Acts become the very nature of the case indispensable for the renewed interest in interpreting sharp disagreement on the role of the Holy Spirit in conversion, empowerment, and the nature of Christian experience with the Holy Spirit. Actually one of the main reasons Luke wrote his Gospel and Acts is to point out the role of the Holy Spirit in effecting miracles and in inspiring witnesses "that have been fulfilled among us" (Luke 1:1). ${ }^{5}$ The rise of the Charismatic Movement and the Pentecostal which also centers on the role of the Holy Spirit and glossolalia merits the need to study in the two narratives by Luke for the church today.

In the Gospel of Luke, certain people are enabled by the Holy Spirit to speak authoritatively in prophecy. Priest Zechariah and his wife, Elizabeth, are enabled by the Holy Spirit to receive the prophecy that they would bear a son to be called John who would be filled with the Holy Spirit even before his birth (Luke 1:13-15). A man called Simeon in Jerusalem is enabled and revealed by the Holy Spirit. He praises God and speaks prophecy (Luke 2:25-35). A prophet called Anna is enabled by the Holy Spirit to "speak about the Child to all who were looking forward to the redemption of Jerusalem" (Luke 2:36-38). John son of Zechariah is revealed by the word of God to speak prophecy in the wilderness (Luke 3:2-19). After Jesus is baptized by John, the Holy Spirit descends on Him in bodily form like a dove, and He opens His ministry way since then (Luke 3:22; 4:1, 14, 18).

According to Luke, the role of the Holy Spirit in the prophecy even before Jesus' birth is to announce the radical newness of God's salvation through His birth. God's Son is born of a virgin, is conceived by the power of the Holy Spirit, and is God Himself coming from the

${ }^{5}$ Cf. J. B. Shelton, Mighty in Word and Deed: The Role of the Holy Spirit in LukeActs, Eugene, OR: Wipf and Stock 2000. Another one reason Luke wrote the Gospel is to enable Theophilus, other Gentiles of his day, and all men of subsequent generations to be certain of the truth about the Christ. 
heaven into this world. The Holy Spirit announces that Jesus is the final and eternal King of Israel (Luke 1:35). Mary is the principal character, and the angel Gabriel is sent from God to speak to her. Therefore, the good news is announced by the angel Gabriel representing as the power of the Holy Spirit to Mary. Mary responds to the Holy Spirit with her faithfulness: "Behold, I am the handmaid of the Lord. May it be done to me according to your word" (Luke 1:38). The Holy Spirit influences Mary for the conception of Jesus. ${ }^{6}$

Another role of the Holy Spirit portrayed by Luke happens in the infancy narrative of Jesus when young Jesus came to the temple. Simeon and Anna are the principal characters who are opened to the Holy Spirit's inspiration to witness Jesus as the Anointed of the Lord and as God's salvation (Luke 2:25-27). The Holy Spirit reveals things to them and enables them to speak authoritatively in prophecy.

On the other hand, comparing with the Holy Spirit working in the lives of John the Baptist and Jesus, first, John was filled with the Holy Spirit while in the womb (Luke 1:15), but Jesus was born of a virgin and was conceived by the power of the Holy Spirit Himself (Luke 1:35). ${ }^{7}$ Second, John cannot release the Spirit being filled in his body to others. But after Jesus was conceived by the power of the Holy Spirit (Luke 3:22), the Spirit can be released through Jesus to become active in others (Luke 3:16). Even John received the Holy Spirit from the presence of Jesus. Third, Jesus was led by the Holy Spirit from one place to another such as to the wilderness (Luke 4:1) ${ }^{8}$ and Galilee (Luke 4:14), to conduct His ministry on earth, while John was not mentioned in Luke if he was led or not by the Spirit. Fourth, the Holy Spirit anointed Jesus to preach good news, to proclaim freedom, to recovery of sight, to release burden, and

${ }^{6}$ See F.S. Spencer, Salty Wives, Spirited Mothers, and Savvy Widows: Capable women of Purpose and Persistence in Luke's Gospel, Grand Rapid, Michigan: William B. Eerdmans Publishing Company 2012, pp. 55-100.

7 Cf. A. B. Spencer, 'Fear' as a witness to Jesus in Luke's Gospel, "Bulletin for Biblical Research" 2 (1992), pp. 59-73.

${ }^{8}$ Cf. M. E. Fuller, Isaiah 40:3-5 and Luke's understanding of the wilderness of John the Baptist, in: Biblical Interpretation in Early Christian Gospels, C. A. Evans (ed.), vol. 3 of the Gospel of Luke, N.Y.: T\&T Clark International: A Continuum Imprint, 2010, pp. 43-58. 
to proclaim the Lord's favor (Luke 4:18), while John was not mentioned in Luke if he was led or not by the Spirit. ${ }^{9}$

In addition, Luke's consideration on the blasphemy of the Holy Spirit has four characteristics. Firstly, Luke warns and encourages believers to avoid sinking into the danger of eternal sin by saying blasphemy against the Holy Spirit. Instead, he encourages believers to confidently rely on the Holy Spirit to give bold inspired witness. Therefore, Luke makes a deliberate choice to drop one synoptic version which he found in Mark and probably Matthew and replace it with a new application. Secondly, Jesus' teaching on the blasphemy against the Holy Spirit in Luke is speaking to His disciples, but the same blasphemy's audience in Matthew and Mark is Jesus' enemies. John M. Creed even resumes that Luke's presentation of the blasphemy against the Holy Spirit preferred a more generalized audience in contrast to a more specific identification in the synoptic parallels of Matthew and Mark. ${ }^{10}$ Thirdly, Luke's presentation of the blasphemy against the Holy Spirit is both sobering and reassuring. Luke warns believers of Jesus eternal apostasy by failure to give inspired witness, which is the blasphemy against the Holy Spirit. Fourthly, Luke includes the blasphemy logion in an abbreviated form when contrasted with Matthew and Mark. Luke only includes one verse on the blasphemy of the Holy Spirit, while Matthew and Mark all include more than one verses. ${ }^{11}$

\section{LUKE'S AND PAUL'S PRESENTATIONS OF THE HOLY SPIRIT}

Both Lukan presentation of the Holy Spirit and Pauline pneumatology connect fullness of the Spirit with inspired speech; that is, Paul speaks to the Ephesians to "be filled with the Spirit" (Ephesians 5:18) and to speak to one another with "spiritual songs" (Ephesians 5:19). Likewise, Luke describes that they "were filled with the Holy Spirit and began to speak in other tongues" (Acts 2:4) at Pentecost. Both of the presentations

9 Cf. J. Kodell, The Gospel According to Luke, vol. 3 of Collegeville Bible Commentary Series, Collegeville, MN: Liturgical Press 1982, pp. 12-23.

${ }^{10}$ Cf. J. M. Creed, The Gospel according to St. Luke: The Greek Text with Introduction, Notes, and Indices, London: Macmillan 1942.

${ }^{11}$ Cf. J.B. Shelton, Mighty in Word and Deed. 
also link the Spirit with effectual prayer; that is, "the Spirit himself intercedes for us with groans that words cannot express" (Romans 8:26), "the Spirit intercedes for the saints in accordance with God's will" (Romans 8:27), and after Peter and John prayed, they are all filled with the Holy Spirit and speak the word of God boldly (Acts 4:31).

Yet there are some profound differences between Pauline and Lukan presentations of the work of the Holy Spirit. Pauline pneumatology is pervasive and broad in its scope, and its influence encompasses nearly all aspects of life and often addresses the role of the Holy Spirit in conversion and who believers are in Christ when he mentions the Holy Spirit. He uses such phrases as "the Spirit of life" (Romans 8:2), "the mind controlled by the Spirit" (Romans 8:6), and being "led by the Spirit" (Romans 8:14) to describe Christian conversion and lifestyle. On the contrary, Lukan presentation is much narrower and put emphasis of the role of the Holy Spirit on power of mission. He uses such phrases as "filled with the Holy Spirit" (i.e., Luke 1:15, 41) and "Jesus, full of the Holy Spirit" (Luke 4:1) or such sentence as "the Holy Spirit was upon him [Simeon]" (Luke 2:25), to indicate that inspired witness, even as the Lord Himself, is about to or has occurred. Another function of the Holy Spirit Luke connects with is to be responsible for praise, joy, miraculous deeds, the kingdom, and with prayer.

Furthermore, Paul's presentation often addresses the question of ontology - that is, what is the Holy Spirit's role in the conversion. While Luke is more interested in the role of the Holy Spirit which empowers believers to witness. Paul and Luke ask different questions of the Holy Spirit, so the activities of the Holy Spirit emphasized by them are somewhat different each other. Many of Luke's distinctive and important messages (i.e., his view of the Spirit) would be lost if bits and pieces of his work were indiscriminately lumped together with Paul's and John's pneumatologies. When one tries to interpret Paul's presentation of the Spirit through Luke's or vice versa, a doctrinal imbalance occurs. ${ }^{12}$ Therefore, it is important to recognize the differences as well as also to know that it does not mean they disagree of the Spirit.

12 Ibid. 


\title{
3. CONCLUSIONS
}

The Church today needs more roles of the Holy Spirit rather than roles of the men to spread the good news of Jesus. Sometimes, the Church solo tracks on some skills, such as certain preaching procedures or brochures (e.g., the Life of Bridge), to attract unbelievers' interest on the good news, but prayers for the Holy Spirit's works on those people are less done comparing with relying on their preaching tricks. We need to go back to the original point to learn how the Church in the first century was prosperous in number and how the good news was spread widely. Luke records in the Acts that the Christians in the era of Jesus' time hard prayed together for seeking the Holy Spirit's coming down. Hence, it should be reminded in the Church today that the Holy Spirit is the original source and power of the good news of Jesus.

\begin{abstract}
This article attempts to preliminarily elucidate the role of the Holy Spirit from the specific eyes of the Lucian Gospel through the following three aspects: (1) the reasons why the messages of the Holy Spirit in Luke among the Synoptic Gospels are significant and unique, (2) Lucan and Pauline perspectives on the Holy Spirit, and (3) Jesus' ministry in the light of the moving of the Holy Spirit. Finally, the article highlights the implications of the Holy Spirit in our modern time.
\end{abstract}

Key words: Holy Spirit; Gospel of Luke.

Streszczenie. Duch Święty w Ewangelii wg św. Lukasza. W tym artykule staram się wstępnie wyjaśnić rolę Ducha Świętego w konkretnej perspektywie Ewangelii wg św. Łukasza w trzech następujących aspektach: (1) powody, dla których przesłania Ducha Świętego w Ewangelii św. Łukasza w świetle ewangelii synoptycznych są ważne i wyjątkowe; 2) Łukaszowa i Pawłowa optyka Ducha Świętego oraz (3) służba Jezusa w świetle poruszenia Ducha Świętego. Na zakończenie ukazane zostają implikacje Ducha Świętego we współczesnym świecie.

Słowa kluczowe: Duch Święty; Ewangelia wg św. Łukasza.

\section{BIBLIOGRAPHY}

Carson D. A., Moo D. J., and Morris L., An Introduction to the New Testament, Grand Rapids, Michigan: Zondervan Publishing House 2005. 
Creed J. M., The Gospel according to St. Luke: The Greek Text with Introduction, Notes, and Indices, London: Macmillan 1942. Fuller M. E., Isaiah 40:3-5 and Luke's understanding of the wilderness of John the Baptist, in: Biblical Interpretation in Early Christian Gospels, C. A. Evans (ed.),vol. 3 of the Gospel of Luke, N.Y.: T\&T Clark International: A Continuum Imprint 2010, pp. 43-58. Groves B., The Gospel According to Luke: Commentary, Abilene, TX: Quality Publications 1991. Kodell J., The Gospel According to Luke, vol. 3 of Collegeville Bible Commentary Series, Collegeville, MN: Liturgical Press 1982, pp. 12-23.

Shelton J. B., Mighty in Word and Deed: The Role of the Holy Spirit in Luke-Acts, Eugene, OR: Wipf and Stock 2000. Spencer A. B., 'Fear' as a witness to Jesus in Luke's Gospel, "Bulletin for Biblical Research" 2 (1992), pp. 59-73.

Spencer F. S., Salty Wives, Spirited Mothers, and Savvy Widows: Capable women of Purpose and Persistence in Luke's Gospel, Grand Rapid, Michigan: William B. Eerdmans Publishing Company 2012. 